\title{
Globalization, localization and language attitudes: the case of "foreign workers" in Singapore
}

Sandra Lee McKay

\author{
Correspondence: 2sandra.mckay@ \\ gmail.com \\ Professor Emeritus, San Francisco \\ State, 1600 Holloway Avenue, San \\ Francisco, CA 94132, USA
}

\begin{abstract}
With labor needs increasing in many developed countries, the mobility among unskilled laborers from less developed countries continues to grow. In understanding this mobility, it is essential to examine the local environment in which it occurs to fully understand its effect on individuals and their language use. The purpose of this paper is to explore some of the parameters that come into play on the local and global level that affect the language experiences and attitudes of individual workers. In accomplishing this goal, I examine the experience of twelve migrant workers to Singapore, a county with an insatiable need for labor, consumed with becoming a key player in the global market, and having a local variety of English that is viewed negatively by many. All of these factors are highly relevant to the experience of foreign workers in Singapore.

In this paper I analyze data gathered from interviews with foreign workers employed in Singapore on their use of English, as well as their attitudes toward Singlish, a local variety of English. Whereas all of them come to Singapore out of a desire to better their economic condition, as well as that of their families, their individual experience in Singapore is greatly affected by gender, by working conditions, and by their own view of themselves as English users. This analysis exemplifies how users of English, sharing similar goals and local conditions, can interpret these experiences in unique ways, demonstrating the need to never neglect individual interpretation in the interplay of globalization and localization.
\end{abstract}

\section{Introduction}

Much has been written about the need to balance global and local factors in dealing with the complexity of current language use, as well as with approaches to second language teaching (Canagarajah, 2005; Mckay, 2008; Rubdy \& Saracent, 2006). Yet little has been written on exactly what is entailed in these global and local parameters and how they interact in cases of individual language users. The purpose of this paper is to explore how global and local concerns interact in the language use and attitudes of a group of foreign workers in Singapore as a way of delineating some of the features that need to be considered in localizing language use and teaching.

The paper begins with a brief look at what is meant by globalization as it relates to language use and attitudes. This overview provides the framework for analyzing the language use and attitudes of twelve foreign workers employed in Singapore. This analysis is undertaken to illustrate the web of global and local factors that come into play in affecting language use in specific contexts. These include, among others, a 
nation's stance toward globalization, its economic wealth and labor needs, mainstream attitudes toward English and migrants, individual education and social class, previous exposure to other languages, and personal motivation and pride. We turn first to what is meant by globalization in the context of this paper.

\section{Globalization}

Many books have been written about the term globalization (Giddens, 1990; Ritzer, 2010; Scholte, 2005). Often these texts emphasize that globalization is far from a new construct; however, what does seem to be unique in this era of globalization is the concept of space. Giddens (1990), for example, contends that this new spatial dimension is such that world wide social relations now "link distant localities in such a way that local happenings are shaped by events occurring many miles away and vice versa” (p. 64). In the case of migrant workers to Singapore, Singapore's need for labor affects the lives of these workers, as well as that of their families and friends. As Hobsbawn (2007) notes, "the impact of globalization is felt by those who benefit from it least." These are the "reserved army of labour of immigrants from villages of great zones of poverty" (as cited in Blommaert, 2010, p. 3).

Scholte (2005), like Giddens, points out the importance of space in the current era of globalization and delineates many other dimensions of current globalization; two of these seem particularly relevant to the current discussion, namely

- The growth of international exchanges; and

- Deterritorialization so that space is no longer mapped in terms of territorial places or borders.

These two features affect current language use in several ways. The growth of international exchange promotes the spread of a common local language or international languages to facilitate communication. In the case of immigrants this language is often the language of the host society, whether it be Japanese for Portuguese immigrants to Japan or German for Turkish immigrants to Germany. For migrant workers, on the other hand, it may be a language of international exchange, such as English, particularly if they have no intention of settling in the country. What makes the Singapore case unusual in this regard is the existence of Singlish, which becomes a basis for some of the workers to positively frame their own English language proficiency. Scholte's second feature emphasizes the fact that nation states are no longer as significant in mapping culture, language use and identity as they used to be. This suggests that the traditional approach of viewing culture and identity largely through the lens of national borders is less viable. In fact the data from this study suggests that national background is less important than class and occupational status in shaping these workers daily experiences.

In this line, Block, Gray and Holborow (2012) argue convincingly that framings of globalization need to shift from a culturally based explanation to a more economically driven explanation. They argue that "while inscriptions such as gender, race, ethnicity, nationality, and sexuality are important in any discussion and analysis of identity, they can blinker researchers as regards hard economic realities which have a great deal of explanatory potential for identity. For this reason, class needs to occupy a more central 
position in language and identity research" (p. 11). They then go on to define social class quite broadly, maintaining that it includes many dimensions, such as wealth, occupation, place of residence, education, social networking, consumption patterns, and symbolic behavior. Symbolic behavior, in their view, includes "how one moves one's body, the clothes one wears, the way one speaks, how one eats, the kinds of pastime one engages in, etc" (p. 81). This particular dimension, as will be shown shortly, plays a significant role in lives of the migrant workers of this study.

Blommaert (2010) emphasizes another critical feature of current globalization, namely mobility. Many individuals today are crossing borders for trade, employment, diplomacy, travel, etc. Some come by choice while others are driven by conditions in their own country, often by poverty, to migrate to other localities. For Blommaert (2010) mobility necessitates that applied linguists carefully examine the local context to understand language use. As he says, "locality and mobility co-exist, and whenever we observe patterns of mobility we have to examine the local environment in which they occur" (p.22). The question is what aspects of globalization, the local environment, and individual interpretation are relevant to an understanding of language use today. What follows is an analysis of the case of sojourn workers in Singapore as a way of shedding light on the varied and complex global, local and individual factors that come into play in how languages are used and viewed today. (For additional details of the study see Rubdy \& McKay, forthcoming).

\section{Foreign workers in Singapore The global context}

In understanding the interplay between global and local forces in reference to language use, it is important to begin with an analysis of the larger context, particularly a nation's outlook toward and participation in current global concerns. Nations can be more or less involved in global trade, diplomacy, education, open borders, etc. Singapore, due to its history, location and small size has chosen to become highly involved in globalization. Because of its desire to play a significant role in international trade and business, it is witnessing great mobility in its population to fulfill its labor needs.

Singapore has one of the largest percentages of foreign-born workers in the world, with 36 percent of its population of 5.2 million a foreign-born worker or 44 percent of the population, if permanent residents are included. This labor force has been a significant factor in the Singapore's transition from a Third World to First World economy. Singapore's management of its foreign-born workers has always relied upon a dual policy that differentiates the highly educated and skilled 'foreign talent' sector, comprising 15 percent of imported labor and the semi- or unskilled 'foreign worker' group that makes up 85 percent, or roughly 1.25 million workers.

For years, Singapore because of its need for labor, has always welcomed foreigners. However, with one in three of the five million people living in Singapore today a foreigner, and citizens complaining about competition for jobs, housing, and medical care, the government has been compelled to take a fresh look at its open-door policy.

\section{The local context}

In so far as a nation's participation in globalization brings with it migration, mainstream citizens can react in various ways to the new "foreign" population. In most 
cases, however, the influx is received with reservation, fear, prejudice and even legal repercussions. Such attitudes, of course, can vary among segments of the population so, for example, while the government or agricultural industry may welcome outside labor, others may resent having people in the society who do not speak the local language and have different ways of behaving.

In Singapore, there is some uneasiness in regard to the position of foreign talent (FT), the highly skilled executive, managerial and professional group comprising expatriates from various Western countries who enjoy certain privileges and the prospect of future residency. Much of the resentment comes from Singaporeans who have to compete directly with foreign engineers, accountants, hotel managers, and technology professionals. The perception that the state cares more for migrant workers than citizens, in fact, became a major issue for the ruling People's Action Party in the recent general elections held in May 2011, with the Opposition strongly insistent that Singaporeans must always come first.

However, it is the foreign workers (FW), rather than foreign talent, who are increasingly visible to the local Singaporean as they go about their every day lives, not just because of their far greater numbers, but also due to the nature of their duties, usually portrayed as the ' 3 Ds' - dirty, difficult and dangerous. And although many if not most Singaporeans may value the services they perform, and the state as a whole benefits from the GDP attributable to foreign workers, it is clear that their presence is being felt in terms of crowded pavement, congested buses and trains, long lines and potentially threatening conduct, all contributing to the anger of local citizens (Shaw \& Ismail 2010: 5).

From the perspective of the FWs, many of whom work in the construction industry, such actions serve to emphasize the marginality of their presence in Singapore. The state's treatment of migrant workers occupying this lower end of the workforce is quite different from that enjoyed by the FT sector, supporting Block, Gray and Holborow's (2012) contention that class can be a critical factor in explaining the effects of globalization. Unlike skilled migrants, unskilled migrants do not have a long term place in Singapore's economy. Their temporary work permits can be terminated during periods of economic downturn. Their living conditions are typically the most basic, living in overcrowded, squalid and unsafe premises that violate safety codes and land use laws, and that are located on the edge of Singapore's built up area, often on industrial land, poorly served by public transportation. Even when facilities are of a good standard, the FWs are treated like inmates, with restrictions placed on the nature of their activities in and around dormitories.

Another group of unskilled migrant workers that has a long history in Singapore are the live-in domestic workers from countries such as Indonesia, the Philippines, Sri Lanka, India and Myanmar. Although their housing conditions are typically better than those who work in the construction industry, over the years many cases of physical and sexual abuse and neglect have been reported in the local and international media. In 2005, Singapore's clean image was severely undermined by an article in the Jakarta Post, which labeled Singapore as a "killing field" based on the findings of a study conducted by the Jakarta-based Institute of ECOSOC Rights (associated with UN's Economic and Social Council), on the conditions of domestic workers in Singapore. The research was prompted by the high incidence of deaths of Indonesian domestic workers which averaged one death per month in the years 1999-2004 (Rahman 2008). 
Although state officials have been at pains to emphasize the economic benefits of having migrant workers and encourage Singaporeans to adopt a more accepting attitude towards the rising numbers of foreigners, Singaporeans continue to perceive them as a threat. Discontent over the perceived special place of foreign talent in Singapore and the increasing presence of low-skilled migrant workers in the country have combined to create a polarization between migrant workers and the rest of Singapore society. One way this polarization becomes evident is in the discourse surrounding the migrants' English language ability.

In public rhetoric, Singaporeans readily equate low-skilled migrant status with poor English skills, and further, with being unfit for the jobs allocated to them. Take, for example, an article in The Straits Times, the major newspaper in Singapore, reporting on a 25 year-old Singaporean who maintained:

I have no issues about foreigners coming here to seek a better life, but it makes no sense that service staff can't speak English. This becomes a hindrance.

(The Straits Times, 30 August 2009)

Discourses that link migration status and language proficiency in this way exemplify the prejudices held by many Singaporeans shaped by deep-seated mainstream language ideologies that emphasize the importance of speaking "Good English." This attitude is epitomized in the Speak Good English Movement initiated in 1999 by Prime Minister Goh Chok Tong. Its goal was to encourage citizens to speak good English on the grounds that using Singlish or Singapore Colloquial English would impede Singaporean's ability to become viable partners in global trade and diplomacy. (For a complete description of the role of English in Singapore, see Lim, Pakir \& Wee, 2010.)

Given the unique web of global and local Singaporean economic, governmental, and social features, we turn now to examining how these influence the language use and attitudes of twelve foreign workers in Singapore.

\section{The foreign workers}

The data for this study is drawn from semi-structured interviews with twelve foreign workers that were carried out in July 2011. The interviewees included six male migrants representing construction workers, three of whom were Indian and three Bangladeshi, and six female domestic workers three of whom were Filipino and three Indonesian. The interviewees were recruited through personal and professional networks. The average time of residence of the interviewees was 6.5 years; three interviewees had arrived two years ago while one of them had just arrived during the previous year. The average age at the time of data gathering was 38 years. (All names are pseudonyms). See Table 1.

The interviews took place at locations convenient to the participants and ranged from 30 to 45 minutes. While the interviews with the male FWs were all conducted one-on-one, in the case of the Filipino and Indonesian domestic workers, they took the form of two separate focus group discussions in keeping with their preference to be interviewed together. Except for the three Filipino domestic workers who were interviewed in English, the interviews were conducted in the interviewee's L1 (Bahasa Indonesia, Bangla, and Tamil) and later translated into English. The interviews were analyzed along several dimensions, including experiences focusing on language 
Table 1 Gender, age, country of origin and length of time spent in Singapore by the foreign workers

\begin{tabular}{llllll}
\hline No & Foreign worker & Gender & Age & Country of origin & Time spent in Singapore \\
\hline 1 & Ravindran & Male & 29 & India & 6 years \\
\hline 2 & Krishnan & Male & 29 & India & 5 years \\
\hline 3 & Nagendra & Male & 40 & India & 9 months \\
\hline 5 & Masud & Male & 31 & Bangladesh & 13 years \\
\hline 6 & Hafiz & Male & 24 & Bangladesh & 4 years \\
\hline 7 & Daisy & Male & 23 & Bangladesh & 3 years \\
\hline 8 & Sylvia & Female & 49 & The Philippines & 16 years \\
\hline 9 & Zeena & Female & 43 & The Philippines & 20 years \\
\hline 10 & Dian & Female & 24 & The Philippines & 1 year, 7 months \\
\hline 11 & Ade & Female & 25 & Indonesia & 2 years \\
\hline 12 & Elsa & Female & 25 & Indonesia & 2 years \\
\hline
\end{tabular}

difficulty, mainstream prejudices, Singlish, and problems that arose in their daily work and life experiences.

Reasons for migration There were obvious differences among the six men and six women in terms of their level of education, their job descriptions and their accommodation patterns. The Indian and Bangladeshi men had had some schooling but had not been able to complete secondary education. While the Indonesian domestic workers had completed secondary school education, two of the Filipino women had attended college, and demonstrated better competence in English than the rest, but chose to come to Singapore because there were not enough jobs available in their own country. The men were mostly engaged in manual labor outdoors, either in available construction and maintenance work or gardening, and all of them complained about the lack of fairness of their pay and poor accommodations. The women, on the other hand, who worked in private homes, cleaning, cooking and taking care of children, seemed more secure. Here again the work and economic background of the participants were an important factor in the migrant's daily experiences.

There were also stark similarities. When asked about their migration objectives, it became clear that the FWs who were in Singapore, particularly the men from Bangladesh and India, had come to Singapore because they were pushed to do so by poverty at home and a deep family commitment. All of them talked about their desire to move out of a life of poverty and believed their time in Singapore would bring them a better life. Sylvia, a Filipino domestic helper spoke of the house she intended to build for her parents and Ravindran, an Indian construction worker, of the business he wished to start when he returned home. Nagendra hoped to save enough money for the marriage dowries of his four daughters in India and Zeena, the other Filipino maid, expressed a desire to fund her niece's and nephew's education in the hopes of bettering their career prospects. Although, with the exception of Sylvia they all had limited competence in English, they claimed that they could get by with their current levels of English in terms of performing their job requirements at least. They did, however, attribute their low status to their limited knowledge of English. 
Competence in English, the language of public exchange Almost all of the interviewees referred to their low competence in English and the problems they encountered in interacting with others. Some talked about the embarrassment and humiliation they experienced caused by the difficulty they have in understanding their employers, as described by the Indonesian domestic helper, Dian:

\section{Extract 1}

Dian: But we have difficulties with our employers. Because of our language barrier, because we speak different languages. If my boss asks me to do, like this, sometimes we don't understand. We want to ask but if we ask, he would not understand also. So sometimes we do things wrongly. Same as what Ade said earlier....They would tease me and laugh, "Dian, I didn't ask you to do that."

Int: Do they laugh light-heartedly or are they angry?

Dian: Sometimes they find us funny because we don't understand what they are asking us to do. We do different things from what they told us to. They would say, "Just now I asked you to find my spectacles, not to go to the refrigerator."

It's funny, so sometimes they are like that. After that they will tell people, "My maid did this this this just now...."

Sometimes we feel cornered because of that. Why must it be like this? Why can't I do it correctly?

Dian's main concern seems to be the embarrassment caused by not understanding the English of her employer ("Sometimes we feel cornered because of that"). Ravindran (Ravi), a Tamil construction worker, however, laments that his English language deficiency poses an obstacle to his ambition to study further and improve his general lot:

\section{Extract 2}

Ravi: If I had known English I would have done my diploma here. My wish is to complete the diploma. I wouldn't think about marriage, if could have studied. I asked many people and realized that it is difficult for me to study. Because there will be a lot of writing to be done.

How the foreign workers deal with negative comments from other Singaporeans also differs among the workers. The general lack of competence in English among this group of sojourners leads a few, like Krishnan (Krish), to become silent as he takes full responsibility for his lack of competence.

\section{Extract 3}

Krish: Yes, but at the same time, if somebody doesn't respect me, I just keep quiet.... 
Because I did not study. If I had studied well, this thing won't have happened to me. I have only myself to blame.

On the other hand, there are those who reject the discrimination they face from other Singaporeans. In referring to the fact that Singapore is a country of immigrants, Sylvia argues against a categorization of members of Singapore society according to their origin, and to the time in history that they may have migrated. She notes that although currently some Singaporeans may be citizens they are not originally from here either.

\section{Extract 4}

Sylvia: What I don't like is the discrimination. The Chinese look at you as some kind of dirt sometimes...Yeah,... even though you speak English better than them they look at you like dirt.

Int: So that's the only thing you dislike, that they look at you as if you're different?

Sylvia: Yes... why like that? We are just the same.

Int: Yes, I agree.

Sylvia: They may be born here but they are not exactly from here. Some of them are from China, some of them are from Malaysia. Singaporeans are not...

Int: Very good point.

Sylvia: We are just sharing one country.

Although more female than male workers voice opposition to the discrimination they face, there are also male workers who refuse to let their lack of fluency in English lower their self-esteem. Ravindran, for example, notes the following.

\section{Extract 5}

Ravi: There is bound to be a difference between the English of educated speakers and our English. But just because we do not know something we cannot say that we are not talented. That's it ...what (qualities) we have they might not have. Not all the people have all the talent. What I can do they will not be able to do...

Ravindran is able to maintain his self-esteem in the midst of discrimination by reminding himself that he can do things others will not be able to do.

While there is then among this group of workers a shared sense of lack of fluency in the needed public language, it is important to note that individuals can address this condition in many ways ranging from accepting blame for the situation to noting their own strengths in other areas. The global/ local interplay is thus always interpreted through an individual who deals with mobility and locality in unique ways. As Mick (2011) points out in reference to migrants, "some of them confirm the mainstream 
ideologies and their social implications, but others transform, reinterpret and transgress hierarchizing borderlines to different extents" (p. 196). There is little doubt that all of the lives of these twelve workers have been strongly influenced by Singapore's role in the global market, as well as by the local labor and social conditions of Singapore. However, how they deal with this situation and what personal attitudes they hold can differ greatly.

Social class and local experiences Earlier I argued along with Block, Gray and Holborow (2012) that social class needs to have a greater explanatory role in applied linguistics. I take social class in a broad sense including not just wealth and education but factors of symbolic behavior such as how one moves and dresses. The importance of dress in reference to local attitudes was vividly depicted in the FW's descriptions of their daily lives.

The Tamil construction worker, Nagendra (Naga), describes how people in the marketplace (Tekka) cringed with discomfort when he passed by, painfully aware that he probably smelled of sweat after a long hard day's labor in the hot outdoors, and wishing he had, like his friends, made use of perfume to neutralize it.

\section{Extract 6}

Naga: I have friends with whom I go to Tekka. They will powder themselves and use perfume. I use only soap and powder. People who are a bit decent they will show their discomfort through facial expressions... may be because of the sweating. This makes me think 'I should also use some perfume, why did I come without it?'

Nagendra is sensitive to how his dress and odor generates a negative response and blames himself for not having used perfume.

Dian, Elsa and Ade, the three Indonesian domestic workers in the corpus, also talk about how appearances and clothes affect the responses they get in public places. However, because of their position and work, they can modify their dress to mitigate some of the negative reactions they receive.

\section{Extract 7}

Dian: Yes, because of language, there are instances. But usually, because we are labeled as 'maids', we are often looked down upon. They may say things like "iiih, you didn't bathe, so you are dirty..."

Elsa: Ya, a lot of people like that. Look down on us lah. Sometimes they say... we ...you know, like we very dirty person or something like that lah. They always look down at maids. Some persons are like that.

Ade: Ya, last time I try right? I try to... I cut like that...err like a maid's appearance and then, they look at me.

Int: Who are they? 
Ade: They are err...sellers... sellers in the market. And then the other day, I went to the same shop, but with a different appearance, ah iya, same like... err a little bit sexy or what. They like ...serve me better. They were like "Miss, miss! What you want to buy? What you want... this this this?"

So I think, I can think, oh, so they think Indonesian maid is like... so dirty or very dishonorable.

Int: Inferior, 'hina' is inferior?

Ade: Inferior, like...

Int : Low, right?

Ade: Yeah, so low. So they think it's only how to say... Only honorable people have high status. Only then they will serve you well. Towards maids, they will think, "ah, this person is not good, and has no money, they won't buy!"

Int: So if you wear like sexy clothes, they will probably think that you are not...

Ade: Not a maid. Ya.

Int: But a rich Indonesian?

Ade: Yeah. They are like that, I think they are that kind of people.

The participants then are aware of how appearances factor into the responses they receive in the society at large. In the case of Ade her experience convinces her that she is judged not by who she is but who others think she is based on her dress and appearance. In the end it is the trappings of class that allow her to be treated respectfully in the market.

Attitudes toward the local variety One aspect of Singaporean society that is mentioned by most of the participants is the widespread use of Singlish or Singaporean Colloquial English within the country. (See McKay and Bokhorst-Heng, 2008, for a complete discussion of the various models used to account for this variety in Singapore.) In general, social class plays a large role in how Singlish is used in Singapore. Often those of higher social class have a full command of both Singlish (often viewed as a basilect variety) and Standard Singapore English. They are able to use the full continuum of English linguistic variation in Singapore to indicate levels of formality and personal identity. On the other hand, individuals of a lower social class tend to have proficiency only in Singlish. These are often individuals of Chinese background who use a Chinese dialect at home and in their immediate community. It is these Singaporeans that the foreign workers in the study tend to marginalize.

When asked about their perceptions of Singapore English, the interviewees had highly evaluative comments to offer, comparing the local variety of English unfavorably with both Filipino and Indian English. Zeena, for example, notes: 


\section{Extract 8}

Zeena: When I first came here I was shocked...Oh they talk English like that? With the... yeah, yeah. I cannot understand. I thought, what are they talking? Then the longer I stay here, then I thought ok, that's Singapore English.

Hafiz is even more negative in his observations, as he makes a distinction between educated Singaporeans who speak English well and 'the rest'.

\section{Extract 9}

Hafiz: I don't think that all Singaporeans speak better English. Those who are educated, who have attended schools/colleges, only they speak English well, otherwise, the rest speak simple English, basic English, it seems as if we (Bangladeshis) speak more normal English than them.

Int: Ok, so you feel that they cannot speak good English, is that it?

Hafiz: Yes, many seem not to speak better English than us. For example, I try in my use of English, I might not be able to use grammar but I take care that within my English I don't use Malay or any other language...but these people don't try it, they just use it.

Krishna is particularly harsh on the use of English among Chinese Singaporeans, pointing out what he feels is a lack of grammar.

\section{Extract 10}

Krish: In India, they will speak with grammar. Here they do not speak with grammar.

Especially when we speak to Chinese, a well educated Indian too cannot understand what they are saying. An educated Indian person can talk very well with an American or Australian person but if you talk to a Chinese even a well educated Indian cannot understand them ....you would already know about it (addressing the interviewer).

Lastly, responding to the interviewer's direct question as to whether she would consider accommodating to Singaporean English, Zeena is quite categorical in distancing herself from the way Singaporeans speak while proudly affirming allegiance to her own Filipino identity ('No, I still want to stick to my...own').

\section{Extract 11}

Int: Have you tried to change the way you speak so that Singaporeans understand you better? Do you feel you need to change?

Zeena: I don't want to say "mah" and "lah" (laughter accompanying her mock intoning of these words in Singlish) 
Int: So you don't want to change to the Singapore accent?

Zeena: No, I still want to stick to my...own.

Int: Ok, what about you, Delia? Sometimes?

Daisy: Their expressions “cannot mah", “cannot lah” It doesn't sound right to me.

Zeena: "Can lah" (in a mimicking tone, smiling naughtily)

Int: So obviously, you don't like to speak like that. And you don't approve of their speaking like that either.

It is clear that the foreign workers in Singapore are largely in Singapore because they are pushed to do so by the poverty at home, and because they wish to improve the lot of their families. In the interviews, while the construction workers tended to adopt discourse strategies which largely confirmed their marginalized positions, such as strategies of silence and blame, the domestic workers often challenged the positionings of social inferiority. There could be several factors contributing to this, such as the socioeconomic status of the home countries they come from, their levels of education as well as their current level of perceived vulnerability as FWs residing in Singapore. While many studies analyzing migrant experiences lump migrants together, as is evident by constant reference to them in the plural and homogenous form overall, it is important to probe further into these diverse factors in assessing and understanding the strategies individuals adopt, the possible reasons for them and how effective they may be in negotiating migrant identities.

\section{Conclusions}

It is clear that today globalization and locality mutually affect one another. As Blommaert (2010) notes,

The world has not become a village, but rather a complex web of villages, towns, neighbourhoods, settlements connected by material and symbolic ties in often unpredictable ways. That complexity needs to be examined and understood. (p. 1)

The purpose of this paper has been to describe that complexity in terms of one group of migrants in one location at a particular time. I have described the manner in which Singapore's desire to be an active participant in the global market influenced the mobility of a small group of foreign workers. The lives of these workers were affected by Singapore's need for labor, by Singaporeans' social attitudes toward migrants, and the existence of a local variety of English. Blommaert (2010) is correct when he argues that "locality and mobility co-exist, and whenever we observe patterns of mobility we have to examine the local environment in which they occur" (p.22). Yet missing from this statement is a recognition of the need to also examine personal interpretation of this mobility and locality as expressed in the attitudes of particular individuals. Whereas all of the twelve workers were placed in the same local context to meet Singapore's labor needs and all faced similar discrimination, language limitations, and exposure to Singlish, their interpretation of these factors differed. 
In the widespread call today to balance global and local factors in examining current language use and learning, it is important to tease out the global and local factors of a particular context that affect language use, attitudes and learning, never neglecting social class as an important factor in language use. It is also important to examine how these factors play out in the attitudes of individual language users. Our goal has been to contribute to this examination so that that we can begin to have a more nuanced understanding of how globalization, with its new sense of space and interdependency, occurs in a specific locality affecting the lives of individual language users.

\section{Competing interest}

The author declares she has no competing interest.

\section{Author's contribution}

SLM undertook this research with R. Rubdy. Additional information regarding the study is available in (Rubdy and Mckay (forthcoming).

Received: 7 March 2012 Accepted: 12 March 2013

Published: 15 May 2013

\section{References}

Block, D, J Gray, and M Holborow. 2012. Neoliberalism and applied linguistics. New York: Routledge. Blommaert, J. 2010. The sociolinguistics of globalization. Cambridge: Cambridge University Press.

Canagarajah, S. (ed). 2005. Reclaiming the local in language policy and practice. Mahwah, NJ: Lawrence Erlbaum Associates.

Giddens, A. 1990. The consequences of modernity. Cambridge: Polity Press.

Hobsbawn. 2007. Globalization, democracy and terrorism. London: Little, Brown.

Lim, L, A Pakir, and L Wee (eds.). 2010. English in Singapore: Modernity and management. Hong Kong: Hong Kong University Press.

McKay, S L, and W D Bokhorst-Heng. 2008. International English in its sociolinguistic contexts. New York: Routledge.

Mick, C. 2011. Discourses of 'border crossers': Peruvian domestic workers in Lima as social actors. Discourse Studies. 13(2): 189-209.

Rahman, N A. 2008. Migrant workers in the Singapore workforce: Managing flows and challenges. http://www.google.com. $\mathrm{sg} /$ search?q=noorashikin+abdul+rahman+-+migrant+workers+in+Singapore\&btnG=Search\&sourceid= navclient\&rlz=1T4SUNC_enSG369SG369\&oq=noorashikin+abdul+rahman+-+migrant+workers+in+Singapore\&aq= f\&aqi=\&aql=\&gs_sm=s\&gs_upl=38375|45523|0|49247|31|31|0|30|0|0|159|159|0.1/1|0 retrieved 17 August 2011.

Ritzer, G. 2010. Globalization: A basic text. Oxford: Wiley Blackwell.

Rubdy, R, S L McKay, and (forthcoming). 'Foreign workers' in Singapore. 2999. Conflicting discourse, language politics and the negotiation of immigrant identities. Int J Sociol Lang.

Rubdy, R, and M Saracent (eds.). 2006. English in the world. London: Continuum.

Scholte, A. 2005. Globalization: A critical introduction. New York: Palgrave.

Shaw, B J, and R Ismail. 2010. 'Good fences make good neighbours'? Geographies of migration: Housing Singapore's Foreign Workers. Paper presented for SEAGA 2010, Hanoi. Online Proceedings.

doi:10.1186/2191-5059-3-3

Cite this article as: McKay: Globalization, localization and language attitudes: the case of "foreign workers" in Singapore. Multilingual Education 2013 3:3.

\section{Submit your manuscript to a SpringerOpen ${ }^{\circ}$ journal and benefit from:}

- Convenient online submission

- Rigorous peer review

- Immediate publication on acceptance

- Open access: articles freely available online

- High visibility within the field

- Retaining the copyright to your article

Submit your next manuscript at $>$ springeropen.com 